\title{
PENGELOLAAN KEASLIAN RASA DAN BUDAYA PADA RESTORAN ETNIK KHAS JAWA: ANALISIS ATMOSPHERIC RESTORAN ETNIK KHAS JAWA DI JAKARTA SELATAN DAN JAKARTA PUSAT
}

\author{
Maria Anggia Widyakusumastuti \\ Marketing Communication Department, Faculty of Economic and Communication, BINUS University \\ Jln. KH. Syahdan No.9, Palmerah, Jakarta Barat 11480 \\ maria.anggia.w@gmail.com
}

\begin{abstract}
This research performed the authenticity of Javanese ethnic flavor and culture in Javanese ethnic restaurant. This research aims to find out how the owners of the restaurant present the authenticity of the flavor and culture through atmospherics elements and challenges they face in bringing the authenticity of the flavor and culture. This study refers to the previous researches published in both national and international journals. The conceptual literature used in this research is Kotler's atmospherics concept. This study provides a conceptual contribution to the study of the introduction of communication science and to contribute the thought on how to convey the authenticity of Javanese flavor and culture, considering that the authenticity cannot be determine objectively, but depends on the social construction. This study used Constructivist Paradigm. This research is a descriptive study with qualitative approach using phenomenology method. Subjects of this research were owners of Javanese ethnic restaurant in South Jakarta and Central Jakarta. Purposive sampling technique was used to select the informants using the snowball method. The validity of the study used a standard of credibility with its own specifications. Presenting the authenticity of Javanese ethnic flavor and culture was not an easy task. The restaurant owners could present through the elements of atmospherics emphasizing the ability of the senses of visual, aural, olfactory, and tactile that captured the stimuli in both the interior and exterior of the restaurant, music, scent of the fragrance of flowers and food, as well as room temperature. In addition to the elements, the owners specially brought and used certain ingredients, such as soy, rice, tofu, crackers, and tea, to keep the authenticity of the taste of Javanese cuisine. They believe that the water and soil texture in Java produce different flavors in those materials.
\end{abstract}

Keywords: authenticity, atmospherics, ethnic restaurant, sensing

\begin{abstract}
ABSTRAK
Penelitian ini membahas tentang keaslian (aunthenticity) rasa dan budaya khas Jawa pada restoran etnik Jawa. Penelitian bertujuan untuk mencari tahu bagaimana upaya pemilik restoran etnik Jawa menghadirkan keaslian (aunthenticity) rasa dan budaya khas Jawa melalui elemen-elemen atmospheric dan tantangan yang dihadapi dalam menghadirkan keaslian (aunthenticity) rasa dan budaya khas Jawa. Penelitian memberikan sumbangan pemikiran bagi studi tentang ilmu pengantar komunikasi dan sumbangan pemikiran untuk mengomunikasikan keaslian (authenticity) rasa dan budaya khas Jawa, mengingat keaslian bukan hal yang dapat didefinisikan secara objektif, melainkan berdasarkan konstruksi sosial. Tinjauan pustaka berangkat dari penelitian terdahulu yang dimuat dalam jurnal nasional maupun internasional. Konsep yang digunakan adalah konsep atmospheric. Penelitian menggunakan Paradigma Konstruktivis. Penelitian ini merupakan penelitian deskriptif dengan pendekatan kualitatif menggunakan metode penelitian fenomenologi. Subjek kajian dalam penelitian ini adalah pemilik restoran etnik khas Jawa yang berlokasi di Jakarta Selatan dan Jakarta Pusat. Pemilihan informan dilakukan dengan menggunakan teknik purposive sampling dengan menggunakan metode snowball. Keabsahan penelitian menggunakan standar kredibilitas dengan spesifikasi tersendiri. Menghadirkan keaslian (authenticity) rasa dan budaya khas Jawa dalam restoran etnik khas Jawa bukan hal yang mudah untuk dilakukan. Salah satu caranya adalah melalui empat elemen atmospheric yang menekankan pada kemampuan indra penglihatan, pendengaran, penciuman, dan peraba dalam menangkap stimulus pada interior dan eksterior restoran, musik, bau wangi bunga dan masakan, serta temperatur ruangan. Selain melalui elemen-elemen pada atmospheric, pemilik restoran etnik khas Jawa mendatangkan dan menggunakan bahan-bahan, seperti kecap, beras, tahu, kerupuk, dan teh untuk menjaga keaslian rasa masakan khas Jawa. Pemilik restoran meyakini bahwa air dan tekstur tanah menghasilkan rasa yang berbeda pada bahan-bahan tersebut.
\end{abstract}

Kata kunci: keaslian, atmosfer, restoran etnik, pengindraan 


\section{PENDAHULUAN}

Indonesia merupakan negeri yang sangat kaya akan keragaman budaya, adat istiadat, bahasa daerah, pakaian daerah, tempat wisata hingga masakan tradisional. Keseluruhan keragaman budaya tersebut wajib dilestarikan agar generasi mendatang tetap dapat mengenal dan merasakan kekayaan budaya negerinya. Tanggung jawab melestarikan keragaman budaya tidak hanya berhenti sampai memperkenalkan pada generasi muda Indonesia, tetapi juga meliputi tanggung jawab memperkenalkan keragaman budaya Indonesia pada dunia internasional.

Kenyataan bahwa Indonesia memiliki kekayaan budaya yang sangat beragam telah membuka banyak peluang bisnis di Indonesia. Salah satunya adalah dengan memperkenalan keragaman budaya kuliner Indonesia. Seiring dengan makin besarnya peluang bisnis kuliner tersebut, maka makin banyak pula restoran etnik khas budaya tertentu yang dapat ditemukan di Indonesia, khususnya di Jakarta. Saat ini, restoran etnik yang sangat mendominasi industri kuliner di Jakarta adalah restoran, atau yang umum dikenal dengan istilah rumah makan, adalah rumah makan khas Minang. Cita rasa masakan yang disajikan di rumah makan khas Minang umumnya telah disesuaikan dengan selera masyarakat sekitar. Hal tersebut sengaja dilakukan sebagai strategi adaptasi orang Minang terhadap norma masyarakat Jawa (Ariyani, 2013). Berbeda dengan rumah makan khas Minang, cita rasa makanan yang disajikan di restoran Jawa umumnya masih dijaga keasliannya.

Restoran etnik merupakan restoran yang mewakili budaya tertentu, yang memberikan kesempatan pada konsumen untuk merasakan sesuatu yang baru dan eksotis (Munoz \& Wood, 2009). Mengacu pada definisi restoran etnik tersebut, maka keaslian merupakan atribut yang sangat erat hubungannya dengan restoran etnik. Menurut Ebster dan Guist (2004), keaslian mengacu pada makanan dan lingkungan (environment) yang dapat mencerminkan rasa yang sebenarnya atau 'real' dan budaya dari etnis tertentu. Dengan demikian, demi mengutamakan keaslian rasa, maka rasa masakan kemudian tidak disesuaikan dengan selera yang telah terlebih dahulu 'akrab' di lidah konsumen.

Restoran etnik bahkan juga digambarkan sebagai duta budaya bagi negara tempat budaya tersebut berasal dan pengalaman makan di restoran etnik tersebut menjadi "wisata kuliner" bagi tamu yang datang (Wood \& Munoz, 2006). Mengacu pada penjelasan Wood dan Munoz (2006), maka restoran etnik khas Jawa dapat dianggap sebagai duta budaya Jawa yang dapat dilihat sebagai salah satu upaya melestarikan dan sekaligus memperkenalkan budaya kuliner Jawa pada masyarakat lokal, khususnya masyarakat Jakarta, dan pada turis mancanegara yang datang berkunjung ke Ibukota Jakarta.

Untuk menciptakan pengalaman unik tentang suatu etnis atau budaya, tidak hanya rasa asli masakan yang memegang peranan penting, tetapi juga suasana (atmospheric) yang mendukung keaslian budaya yang diusung oleh restoran etnik harus dipersiapkan dengan matang oleh pemilik restoran. Keaslian (authenticity) atmospheric yang terdapat pada restoran etnik dapat mempengaruhi emosi positif dan negatif secara signifikan. Kedua jenis emosi tersebut dapat menjadi mediator yang menghubungkan keaslian atmospheric dan keinginan berperilaku (Jang et. Al, 2010). Keaslian atmospheric dapat menghadirkan keaslian (authenticity) rasa dan budaya yang diusung oleh sebuah restoran. Dengan demikian, atmospheric dapat menjadi media untuk menciptakan pesan keaslian (authenticity) tersebut.

Restoran etnik umumnya mudah dikenali dari pilihan menu makanan yang ditawarkan, hingga dekorasi interior maupun eksterior yang digunakan. Menu makanan yang ditawarkan adalah makanan yang menjadi ciri khas dari daerah yang sesuai dengan budaya etnis restoran tersebut, demikian juga dengan hiasan atau dekorasi yang dipakai. Demikian pula dengan restoran etnik khas Jawa yang dapat 
dengan mudah dikenali, mulai dari bentuk bangunan, hiasan interior khas Jawa hingga pilihan menu masakan khas Jawa. Maka tamu yang datang dapat merasakan pengalaman unik khas Jawa ketika mengunjungi restoran etnik khas Jawa tersebut.

\section{Permasalahan}

Komunikasi merupakan sebuah proses sosial, yang di dalamnya individu-individu yang terlibat menggunakan simbol-simbol dalam menyampaikan pesan mereka serta memaknai simbolsimbol tersebut dalam lingkungan mereka (West \& Turner, 2011). Penyampaian pesan dalam proses komunikasi tidak selalu berjalan dengan mulus. Hal tersebut disebabkan penggunaan dan pemaknaan simbol sangat dipengaruhi oleh latar belakang masing-masing individu yang terlibat didalamnya. Tidak hanya proses komunikasi dalam kehidupan sehari-hari, penggunaan dan pemaknaan simbol juga dilakukan dalam mengomunikasikan pesan keaslian (authenticity) dalam industri kuliner, khususnya pada restoran dengan kategori restoran etnik khas Jawa.

Mengomunikasikan pesan keaslian (authenticity) pada restoran etnik khas Jawa bukanlah sebuah perkara yang mudah. Menurut Grazian (2003), keaslian (authenticity) merupakan kemampuan suatu tempat atau peristiwa (atau objek) untuk menyesuaikan dengan cerminan realitas yang ideal, yaitu serangkaian harapan tentang bagaimana sesuatu seharusnya terlihat dan dirasakan. Penilaian terhadap keaslian (authenticity) pada restoran etnik khas Jawa kemudian tergantung pada kesepakatan pemaknaan masyarakat etnis Jawa di daerah asal. Dengan demikian, keaslian (authenticity) bukanlah sesuatu yang dapat didefinisikan secara objektif, melainkan tergantung pada realitas sosial yang terbentuk di masyarakat.

Pemilik restoran etnik khas Jawa kemudian perlu mempertimbangkan dengan baik setiap hal yang akan dipergunakan demi mengomunikasikan keaslian (authenticity) rasa dan budaya khas Jawa di dalam restorannya. Hal-hal yang harus dipertimbangkan meliputi berbagai hal, seperti bahan-bahan makanan yang digunakan, musik, hingga dekorasi yang dipakai dalam restoran.

\section{Pertanyaan Penelitian}

Berdasarkan permasalahan tersebut, maka muncul pertanyaan penelitian sebagai berikut. Pertama, bagaimana upaya pemilik restoran etnik khas Jawa dalam menghadirkan keaslian (authenticity) rasa dan budaya khas Jawa di dalam restorannya? Kedua, apa saja kendala-kendala yang dihadapi dalam menghadirkan keaslian (authenticity) rasa dan budaya khas Jawa tersebut?

\section{Studi Literatur}

Kotler (1973) mendefinisikan atmospheric sebagai upaya merancang suatu lingkungan agar dapat menghasilkan efek emosional tertentu bagi pembeli, yang mana pada akhirnya dapat meningkatkan kemungkinan pembeliannya. Atmospheric dapat dirasakan melalui indra (sense) manusia. Adapun kategori atmospheric yang dijelaskan oleh Kotler meliputi: (a) indra penglihatan (visual): meliputi color, brightness, size, dan shape; (b) indra pendengaran (aural): meliputi volume dan pitch; (c) indra penciuman (olfactory): meliputi scent dan freshness; (d) indra sentuhan (tactile): meliputi temperatur, softness, dan smoothness.

Atmospheric dapat dilihat, didengar, dibaui, dan disentuh, tetapi tidak dapat dikecap (taste). Bagaimanapun, penggunaan artefak tertentu dapat mengaktifkan ingatan manusia akan rasa (taste). Turley dan Milliman (2000) menunjukkan bahwa kategori "general interior” atau interior atmospheric secara umum adalah (i) ambient, meliputi musik, suara, pencahayaan, bau, warna, temperatur; dan (ii) elemen desain visual. 
Atmosphere sendiri memiliki empat fungsi utama, yaitu sebagai berikut. Pertama sebagai attention-creating medium, yaitu media yang dapat menciptakan perhatian tertentu. Hal-hal yang tidak biasa dilihat, dicium, didengar, maupun dirasakan dapat menjadi stimulus yang dapat dengan mudah ditangkap oleh indra manusia. Kedua sebagai message-creating medium, yaitu media yang dapat menciptakan pesan tertentu. Bentuk bangunan, artefak-artefak tertentu dapat menjadi pesan tersendiri bagi orang-orang yang melihatnya. Ketiga sebagai affect-creating medium, yaitu media yang dapat menciptakan dampak tertentu. Berbagai elemen dari atmospheric dapat menciptakan dampak tertentu bagi orang yang merasakannya. Keempat sebagai mood-creating medium, yaitu media yang dapat menciptakan mood atau suasana hati tertentu.

\section{METODE}

Penelitian ini menggunakan Paradigma Konstruktivis. Paradigma Konstruktivis memulai premis yang menganggap bahwa dunia manusia berbeda dengan dunia ilmu alam sehingga harus diteliti secara berbeda pula. Hal ini disebabkan manusia mengembangkan kapasitas untuk menginterpretasi dan mengonstruksi realitas, dan bukan sebaliknya. Dunia persepsi manusia bukanlah kenyataan yang sebenarnya sebagaimana dunia ilmu alam seperti matahari terbit dari arah timur, melainkan dibuat dan dibentuk oleh konstruksi budaya dan bahasa. Oleh karena itu, paradigma konstruktivis meneliti berbagai realitas yang dikonstruksi oleh orang dan implikasi dari hasil konstruksi tersebut terhadap kehidupan dan interaksinya dengan orang lain (Patton, 2002).

Secara ontologi paradigma ini mengasumsikan bahwa realitas sosial bersifat lokal, spesifik, dan merupakan produk dari konstruksi sosial (realtivistik). Secara epistemologis, hubungan peneliti dengan yang diteliti bersifat transaksional (subjektivistik), yaitu bahwa hubungan peneliti dan yang diteliti selalu dijembatani oleh nilai-nilai tertentu. Pemahaman tentang suatu realitas atau temuan peneitian merupakan interpretasi peneliti dari kacamata nilai atau ideologi tertentu. Secara metodologis paradigma ini akan menggunakan serangkaian prosedur metodologis dalam suatu lingkungan yang alami (in verbal world) dan bersifat heurmenetikal atau dialektikal (Neuman, 2003).

Oleh sebab itu data dalam penelitian dengan menggunakan paradigma konstruktivis "bersifat subjektif", dalam arti didasarkan atas pandangan pihak yang diteliti. Mereka (yang diteliti) diperlakukan sebagai subjek penelitian yang memiliki pandangan tertentu atas apa yang menjadi perhatian si peneliti. Dengan demikian, data dalam paradigma kontruktivis haruslah mencerminkan “apa yang dirasakan dan yang ingin disampaikan oleh pihak yang diteliti (subjek penelitian)”, bukan apa yang ingin diceritakan oleh si peneliti. Sehingga di sini peneliti harus menyelami (embodied) alam pikiran subjek penelitian agar dapat diperoleh perspektif yang bersifat subjektif tersebut (Patton, 2002).

Pendekatan penelitian ini menggunakan pendekatan penelitian kualitatif deskriptif. Penelitian deskriptif memfokuskan pada pertanyaan "bagaimana" dan "siapa”. Penelitian ini lebih memfokuskan pada penggambaran bagaimana sebuah peristiwa terjadi, dan bukan pada penggalian isu-isu yang baru (Neuman, 2003).

Peneliti deskriptif menggunakan berbagai teknik pengumpulan data, antara lain survei, penelitian lapangan, analisis isi, komparasi sejarah, atau pada kasus-kasus tertentu digunakan penelitian eksperimental. Penelitian deskriptif menyuguhkan gambaran atas detail-detail secara spesifik dari sebuah peristiwa, setting sosial, atau hubungan antarpihak yang diteliti.

Penelitian deskriptif memiliki banyak kesamaan dengan penelitian eksploratif. Dalam pelaksanaannya mereka bahkan sering kali membaur. Dalam penelitian deskriptif, peneliti memulai dengan subjek yang didefinisikan secara sempurna dan melakukan penelitian untuk menggambarkan 
subjek penelitian secara akurat. Hasil dari penelitian deskriptif adalah gambaran mendetail dari subjek penelitian. Penelitian deskriptif menyuguhkan gambaran atas berbagai jenis manusia atau aktivitas sosial. Jadi penelitian deskriptif yang dilakukan akan berusaha mendeskripsikan atau menggambarkan tentang upaya pemilik restoran etnik khas Jawa dalam menghadirkan keaslian (authenticity) rasa dan budaya Jawa di dalam restorannya.

Lokasi penelitian ini bertempat di dua restoran etnik khas Jawa di Jakarta Selatan dan Jakarta Pusat. Dalam penelitian ini, metode pengumpulan data yang digunakan adalah berikut ini. (1) Data primer: penelitian primer membutuhkan data atau informasi dari sumber pertama, biasanya disebut sebagai responden. Data atau informasi diperoleh melalui pertanyaan tertulis dengan menggunakan kuesioner atau lisan dengan menggunakan metode wawancara (Sarwono, 2006); (a) wawancara mendalam (in-depth interview), menurut Bungin (Hamidi, 2007), "wawancara mendalam adalah suatu proses memperoleh keterangan untuk tujuan penelitian dengan cara tanya jawab sambil bertatap muka antara pewawancara dengan informan atau orang yang diwawancarai, dengan atau tanpa menggunakan pedoman wawancara, yang pewawancara dan informan terlibat dalam kehidupan sosial yang relatif lama." Metode wawancara yang digunakan dalam penelitian ini adalah wawancara langsung, dengan penulis melakukan komunikasi verbal dengan orang yang menjadi sumber data secara langsung, tanpa perantara, baik tentang diri dan segala sesuatu yang berhubungan dengan dirinya. (b) Observasi, merupakan metode pengumpulan data yang dilakukan peneliti untuk mengamati atau mencatat suatu peristiwa dengan penyaksian langsungnya dan biasanya peneliti dapat sebagai partisipan atau observer dalam menyaksikan atau mengamati suatu objek peristiwa yang sedang ditelitinya (Ruslan, 2008). (2) Data sekunder; menggunakan bahan yang bukan dari sumber pertama sebagai sarana untuk memperoleh data atau informasi untuk menjawab masalah yang diteliti (Sarwono, 2006). Selain menggunakan wawancara dan observasi, data sekunder dibantu dengan dokumentasi. Dokumentasi merupakan metode pengumpulan data dengan cara mengambil data yang berasal dari dokumen asli. Dokumen asli tersebut dapat berupa gambar, tabel, atau daftar periksa dan film dokumenter (Hamidi, 2007).

Sebuah penelitian kualitatif yang menggunakan wawancara mendalam, terkait erat dengan narasumber penelitian atau informan. Menurut Moleng (2005), informan merupakan individu yang dimanfaatkan untuk memberikan informasi tentang situasi dan kondisi latar penelitian. Jadi, informan harus mempunyai banyak informasi tentang situasi dan kondisi latar penelitian. Ia berkewajiban secara sukarela menjadi anggota tim dengan kebaikan dan kesukarelaan tentang nilai-nilai, sikap, bangunan, dan kebudayaan yang menjadi latar penelitian tersebut. Dalam penelitian ini, informan yang diambil oleh peneliti adalah informan yang telah menjalankan bisnis kuliner, yaitu restoran etnik khas Jawa selama lebih dari tiga tahun, bertanggung jawab secara penuh dalam menghadirkan keaslian (authenticity) rasa dan budaya khas Jawa, mulai dari perencanaan hingga pengawasan pelaksanaan di lapangan. Atas permintaan informan, maka nama restoran dirahasiakan. Informan berjumlah dua orang, yaitu Informan 1: PVT (35 tahun), perempuan, pemilik restoran etnik khas Jawa di Jakarta Selatan; informan 2: ADP (39 tahun), laki-laki, pemilik restoran etnik khas Jawa di Jakarta Pusat.

Teknik analisis data yang digunakan dalam penelitian kualitatif adalah analisis data secara induktif. Analisis induktif ini digunakan karena beberapa alasan. Pertama, proses induktif lebih dapat menemukan kenyataan-kenyataan ganda sebagai yang terdapat dalam data. Kedua, analisis induktif lebih dapat membuat hubungan peneliti-responden menjadi eksplisit, dapat dikenal, dan akuntabel. Ketiga, analisis demikian dapat menguraikan latar secara penuh dan dapat membuat keputusankeputusan tentang dapat-tidaknya pengalihan kepada suatu latar lainnya. Keempat, analisis induktif lebih dapat menemukan pengaruh bersama yang mempertajam hubungan-hubungan. Kelima, analisis demikian dapat memperhitungkan nilai-nilai secara eksplisit sebagai bagian dari struktur analitik.

Analisis data adalah proses mengorganisasikan dan mengurutkan data ke dalam pola, kategori, dan satuan uraian dasar sehingga dapat ditemukan tema dan dapat dirumuskan hipotesis kerja seperti yang disarankan oleh data. Penelitian menggunakan metode analisis naratif. Inti dari metode ini adalah 
kemampuannya untuk memahami identitas dan pandangan dunia seseorang dengan mengacu pada cerita-cerita (narasi) yang ia dengarkan atau tuturkan di dalam aktivitasnya sehari-hari (baik dalam bentuk gosip, fakta, berita, analisis, dan sebagainya, karena semua itu dapat disebut sebagai cerita). Fokus penelitian dari metode ini adalah cerita-cerita yang didengarkan di dalam kehidupan manusia sehari-hari. Di dalam cerita atau narasi, kompleksitas kultural kehidupan masyarakat ditangkap dan dituturkan dalam bahasa. Dalam konteks ini, cerita bukan sekadar cerita, melainkan menjadi bagian dari penelitian untuk memahami manusia dan dunianya, kemudian secara tetap membandingan satu data dengan data lainnya atau kategori lainnya (Webster \& Mertova, 2007).

Analisis data adalah proses mengatur urutan data, mengorganisasikannya ke dalam suatu pola, kategori dan satuan uraian dasar. Ia membedakannya dengan penafsiran, yaitu memberikan arti yang signifikan terhadap hasil analisis, menjelaskan pola uraian, dan mencari hubungan diantara dimensidimensi uraian. Bogdan dan Taylor (dalam Moleong, 2005), mendefinisikan analisis data sebagai proses yang terinci dari usaha formal untuk menemukan tema dan merumuskan hipotesis kerja (ide) seperti yang disarankan oleh data sebagai usaha untuk memberikan bantuan pada tema dan hipotesis kerja itu. Proses analisis data dimulai dengan menelaah seluruh data yang tersedia dari berbagai sumber, yaitu wawancara, pengamatan yang dituliskan dalam catatan lapangan, dokumen pribadi, dokumen resmi, gambar, foto, dan sebagainya (Moleong, 2005).

Subjektivitas peneliti biasanya menjadi hal yang dominan dalam penelitian kualitatif. Alat penelitian yang diandalkan adalah observasi dan wawancara mendalam, yang mengandung banyak kelemahan ketika dilakukan apalagi tanpa kontrol. Sumber data kualitatif diasumsikan kurang credible dan akan memengaruhi akurasi penelitian. Menurut Bryman (2008) ada beberapa cara menentukan keabsahan data penelitian kualitatif, sebagai berikut.

Credibility (kredibilitas); mengacu pada apakah proses dan hasil penelitian dapat diterima atau dipercaya. Penerapan derajat kepercayaan pada darnya menggantikan konsep validitas internal dari non-kualitatif. Dalam menguji keabsahan data, peneliti menggunakan teknik observasi secara terus menerus, dan cermat, sehingga peneliti dapat melihat secara langsung dan dapat memaparkan fenomena sosial yang diteliti seperti apa adanya. Dalam penelitian ini peneliti melakukan verbatim dari wawancara dan coding, sehingga dapat menganalisis secara akurat.

Transferability (transferabilitas); mengacu pada apakah hasil penelitian ini dapat diterapkan pada situasi yang tidak serupa atau lain. Konsep validitas itu menyatakan bahwa generalisasi suatu penemuan dapat berlaku atau diterapkan pada semua konteks dalam populasi yang sama atas dasar penemuan yang diperoleh pada sampel yang secara representatif mewakili populasi tersebut. Dalam penelitian ini kualitas transferabilitas menyajikan data deskriptif, misalnya melalui latar belakang informan, dan peran informan dalam institusinya.

Dependability (ketergantungan); mengacu pada konsistensi peneliti dalam mengumpulkan data, membentuk, dan menggunakan konsep-konsep ketika membuat interpretasi untuk menarik simpulan. Penarikan simpulan dalam penelitian ini dilakukan secara cermat dan konsisten berdasarkan observasi dan wawancara mendalam yang sudah dilakukan oleh peneliti.

Confirmability (konfirmabilitas); mengacu pada apakah hasil penelitian dapat dibuktikan kebenarannya, apakah hasil penelitian sesuai dengan data yang dikumpulkan. Hal tersebut dilakukan dengan cara memperlihatkan hasil penelitian pada informan atau mengkonfirmasi ulang jawaban informan sehingga hasil penelitian lebih objektif. 


\section{HASIL DAN PEMBAHASAN}

Di tengah ketatnya persaingan bisnis kuliner saat ini, kehadiran restoran etnik khas Jawa makin mewarnai ramainya industri makanan di Jakarta. Agar dapat bertahan di tengah persaingan bisnis makanan yang kian tajam, keaslian (authenticity) rasa dan budaya khas Jawa menjadi atribut utama dalam restoran etnik khas Jawa. Tanggung jawab para pemilik restoran etnik khas Jawa juga menjadi kian berat. Panggilan untuk terus dapat melestarikan budaya Jawa telah menjadi alasan utama para pemilik restoran ketika memutuskan untuk mendirikan restoran mereka. Baik konsumen lokal maupun wisatawan asing yang hanya sempat berkunjung ke Jakarta diharapkan dapat tetap merasakan suasana khas Jawa di tengah hiruk pikuk Ibukota Jakarta.

Mengingat keaslian (authenticity) rasa merupakan hal yang tidak dapat didefinisikan secara objektif (Grazian, 2003), maka menghadirkan suasana khas Jawa kemudian menjadi tantangan tersendiri bagi para pemilik restoran etnik khas Jawa. Salah cara untuk dapat tetap menghadirkan keaslian (authenticity) rasa dan budaya Jawa adalah dengan menciptakan atmosphere khas Jawa, yaitu dengan memastikan bahwa segala sesuatu yang dilihat, didengar, dicium, dan dirasakan oleh tamutamu yang datang ke restoran mereka dapat membuat para tamu merasakan pengalaman unik seolaholah sedang berada di Jawa.

\section{Visual}

Seperti yang telah dijelaskan oleh Kotler (1973), dan Turley dan Milliman (2000), segala sesuatu yang dapat dilihat oleh manusia menjadi stimulus bagi indra penglihatan. Banyak sekali media yang dipakai untuk menciptakan stimulus bagi indra penglihatan di restoran etnik khas Jawa. Hal itu dimulai dari bentuk dan ukuran bangunan, warna yang ada di dalam interior ruangan restoran, hiasan interior restoran, seragam dan penampilan para pelayan, buku menu, peralatan makan, hingga presentasi atau penyajian makanan. Semua hal tersebut dapat menghadirkan keaslian (authenticity) rasa dan budaya khas Jawa di dalam restoran, yang pada akhirnya dapat memberikan pengalaman unik bagi para tamu yang datang.

Rumah khas Jawa adalah rumah joglo. Hingga saat ini, rumah joglo masih dapat dengan mudah ditemukan di berbagai tempat di Jawa Tengah. Berada di antara bangunan-bangunan bertembok dan gedung-gedung pencakar langit di Jakarta, rumah Joglo dapat dengan mudah menarik perhatian setiap orang, sehingga menjadi stimulus yang sempurna bagi indra penglihatan manusia. Bangunan restoran berbentuk joglo juga menjadi pesan yang tepat untuk memberitahukan bahwa restoran tersebut adalah restoran etnik khas Jawa. Selain bangunan restoran berbentuk joglo, ukuran bangunan dan halaman yang luas juga menjadi faktor penting bagi pemilik restoran untuk menampilkan kekhasan rumah Jawa.

Warna coklat yang mendominasi desain interior maupun eksterior bangunan juga menjadi stimulus yang tepat bagi para tamu. Budaya khas Jawa identik dengan perabot berbahan kayu. Penggunaan furnitur, seperti meja dan kursi secara keseluruhan berbahan kayu jati dan didatangkan langsung dari Jepara, salah satu kota di Jawa Tengah yang terkenal dengan hasil kerajinan ukiran kayu khas Jawa. Meskipun furnitur berbahan kayu sebenarnya dapat dengan mudah diperoleh di Jakarta, demi menghadirkan keaslian suasana Jawa, sebagian besar furnitur didatangkan khusus dari Jepara. Pemilik restoran percaya bahwa ada penyatuan jiwa antara pengrajin kayu dan hasil karyanya, yang dapat makin menghadirkan keaslian budaya khas Jawa.

Selain kayu, budaya Jawa juga identik dengan batu dan wayang. Pemilik restoran menempatkan artefak-artefak dari batu, berupa stupa-stupa untuk mengingatkan para tamu bahwa Jawa juga identik dengan candi. Selain stupa dari batu, pemilik restoran juga memasang hiasan wayang kulit sebagai hiasan interior restoran. Wayang sendiri memiliki falsafah budaya Jawa yang sangat kental dan kaya. 
Di salah satu restoran, bahkan pemiliknya menempatkan gerobak sate, pikulan soto, dan lesehan untuk 'mbok' nasi liwet (istilah untuk ibu-ibu yang menjual nasi liwet di Jawa) di bagian depan restoran. Hal tersebut bertujuan untuk makin menghadirkan suasana tradisional Jawa. Tidak hanya berfungsi sebagai hiasan, para tamu juga dapat melihat langsung bagaimana makanan yang mereka pesan dimasak dan diracik langsung oleh juru masaknya.

Selain bentuk bangunan dan hiasan interior yang khas Jawa, penampilan para pelayan juga menjadi faktor penting untuk menghadirkan keaslian budaya Jawa di restoran etnik khas Jawa. Pelayan perempuan mengenakan kebaya model kutu baru berbahan sembagi (kain transparan semacam kain voil) dengan motif bunga-bunga dan jarik khas Solo. Pakaian yang sama adalah pakaian tradisional yang sehari-hari dikenakan para perempuan Jawa. Rias wajah sederhana dan gelung rambut tanpa sasak juga menjadi penampilan sehari-hari para perempuan Jawa. Sementara itu, pelayan lakilaki mengenakan kemeja batik lengan pendek dan blangkon (penutup kepala khas Jawa) dengan motif yang sama dengan jarik pelayan perempuan. Pemandangan yang sama merupakan pemandangan yang umum dilihat di Jawa, bertujuan untuk memberikan pengalaman khas Jawa bagi para tamu.

Di samping penampilan pelayan yang mencerminkan penampilan sehari-hari masyarakat Jawa, peralatan makan yang disesuaikan dengan peralatan makan yang umum dipakai di Jawa juga dapat menciptakan pengalaman makan yang unik khas Jawa. Para pemilik restoran secara khusus membeli peralatan makan, seperti sendok, garpu, piring, mangkok, dan gelas langsung dari Jawa. Selain karena alasan harga yang lebih murah, peralatan makan masyarakat Jawa berbeda dengan peralatan makan yang digunakan masyarakat Jakarta pada umumnya. Meskipun sama-sama berbahan besi tahan karat, kandungan besi pada sendok dan garpu berbeda. Sendok dan garpu khas Jawa memiliki penampilan yang tidak mengkilap dan jauh lebih ringan dibanding sendok dan garpu yang umum ditemukan di Jakarta. Piring dan mangkok berbahan keramik dengan motif bunga, dan gelas belimbing juga menjadi pemandangan yang sudah sangat jarang dilihat di Jakarta. Sebaliknya, masyarakat Jawa pada umumnya masih menggunakan peralatan makan tersebut. Melalui peralatan makan yang disesuaikan dengan peralatan makan sehari-hari di Jawa, para pemilik restoran etnik khas Jawa berharap dapat menciptakan pesan tradisional Jawa dan semakin memberikan keaslian suasana Jawa pada para tamu yang datang.

Makanan merupakan produk utama yang dijual di sebuah restoran. Dengan demikian, penyajian atau presentasi makanan harus dapat membangkitkan selera makan tamu yang datang. Penyajian atau presentasi makanan yang mampu menghadirkan keaslian (authenticity) rasa dan budaya Jawa di restoran etnik khas Jawa berasal dari penggunaan daun pisang, daun jati, dan sereh. Piring yang digunakan untuk masakan yang tidak berkuah atau yang hanya sedikit berkuah akan diberi alas daun pisang. Penyajian nasi dibungkus menggunakan daun jati. Sedangkan makanan dan minuman yang menggunakan sereh, sengaja diberikan sereh dalam bentuk batangan yang besar-besar.

Hal lain yang dapat menciptakan keaslian (authenticity) budaya Jawa adalah pencahayaan ruangan. Pencahayaan ruangan dapat menjadi media yang menciptakan pesan, dampak, dan mood tertentu bagi tamu yang datang. Pencahayaan restoran yang terang umum digunakan. Tujuannya adalah agar tamu dapat dengan jelas melihat presentasi makanan dan diharapkan dapat membangkitkan selera makan para tamu. Sebaliknya pencahayaan yang tidak terlalu terang atau remang-remang pada umumnya untuk menciptakan suasana hangat dan romantis. Pencahayaan ruangan di restoran etnik khas Jawa menggunakan lampu yang tidak terlalu terang, sehingga menghasilkan pencahayaan yang remang-remang. Namun tujuan pemilik restoran menampilkan pencahayaan yang remang-remang di restoran mereka bukan untuk menciptakan suasana romantis, melainkan untuk menciptakan pesan keaslian suasana rumah di Jawa pada umumnya, dan untuk makin menciptakan pengalaman seolah-olah sedang berada di Jawa. Hingga saat ini, sebagian besar rumah tinggal dan restoran di Jawa masih menggunakan penerangan dengan lampu teplok atau lampu berbahan minyak tanah. 


\section{Aural}

Musik dan volume suara merupakan elemen-elemen dalam atmospheric yang dapat menjadi stimulus bagi indra pendengaran manusia (Kotler, 1973). Gamelan dan siter merupakan alat musik tradisional khas Jawa, sehingga identik dengan budaya Jawa. Alunan suara gamelan, siter, tembangtembang Jawa dan lagu campur sari yang dibawakan oleh sinden dapat menjadi stimulus yang tepat bagi pendengaran. Setiap malam minggu, para tamu dari kedua restoran dapat menikmati alunan gamelan dan tembang Jawa klasik maupun lagu campur sari, sedangkan pada hari biasa, para tamu dapat menikmati alunan suara yang berasal dari alat musik siter.

Keaslian (authenticity) budaya Jawa dapat dihadirkan melalui alunan musik yang berasal dari gamelan dan tembang yang dinyanyikan para sinden. Para pemilik restoran memilih untuk menggunakan gamelan asli, bukan kaset, untuk menyampaikan pesan keaslian pada para tamu yang datang. Alunan musik gamelan dan siter yang perlahan juga dapat menciptakan mood yang menenangkan dan sakral, seperti suasana di keraton Jawa.

\section{Olfactory}

Menurut Kotler (1973), indra penciuman manusia dapat menangkap stimulus berupa bau dan kesegaran (freshness). Bau tertentu dapat menciptakan dampak tertentu bagi orang yang menciumnya. Tidak seperti kebanyakan restoran di Jakarta yang menggunakan pengharum ruangan buatan pabrik, kesegaran dan bau wangi ruangan justru dihasilkan dari bau bunga asli. Bau pandan, bunga melati, dan bunga sedap malam merupakan bau yang identik dengan budaya Jawa dan dapat menggambarkan suasana khas keraton Jawa. Selain menghasilkan bau wangi, pandan dan melati juga menghasilkan kesegaran. Bau restoran yang segar mencerminkan kehigienisan atau restoran yang bersih. Pemilik restoran etnik khas Jawa menempatkan mangkok berisi irisan daun pandan dan bunga melati di setiap meja di dalam restoran. Rangkaian bunga sedap malam juga selalu menghiasi setiap sudut restoran. Bau wangi dari pandan, bunga melati, dan bunga sedap malam dapat menjadi media untuk menciptakan suasana khas Jawa di dalam restoran mereka.

Selain bau wangi yang dihasilkan dari pandan, bunga melati, dan bunga sedap malam, salah satu pemilik restoran etnik khas Jawa menggunakan konsep open kitchen atau konsep dapur terbuka, tetapi tidak transparan. Tamu tidak bisa melihat proses memasak namun dapat mencium bau masakan. Bau masakan diyakini dapat membangkitkan selera makan tamu yang datang. Setiap makanan masih dimasak dengan teknik memasak tradisional dan menggunakan kompor dengan bahan bakar arang. Bau masakan yang dimasak dengan kompor berbahan bakar arang memiliki bau yang khas. Bau khas tersebut akan menghadirkan keaslian rasa masakan khas Jawa.

\section{Tactile}

Elemen terakhir dari atmospheric adalah temperatur atau suhu ruangan. Rumah tradisional di Jawa tidak menggunakan pendingin ruangan atau air conditioner (AC). Kesejukan ruangan lebih banyak dihasilkan dari angin dan sirkulasi udara yang baik. Rumah joglo memiliki ciri atap yang tinggi di tengah ruangan sehingga memungkinkan sirkulasi udara yang baik. Untuk menjaga keaslian (authenticity) budaya Jawa, pemilik restoran etnik khas Jawa tidak menggunakan pendingin ruangan (AC), tetapi memilih menggunakan kipas angin.

Penggunaan kipas angin di dalam restoran juga atas pertimbangan karena adanya konsep open kitchen atau dapur terbuka, yang karena kipas tersebut bau masakan dapat dengan mudah keluar dari dapur dan tercium oleh para tamu. Namun dengan adanya kipas angin dan sirkulasi udara yang baik, bau masakan tidak menempel di pakaian para tamu, tetapi dapat keluar dari ruangan restoran dan bertukar dengan udara segar dari luar ruangan. 
Selain elemen-elemen atmospheric yang telah dijelaskan, ada satu hal yang sangat menarik sehubungan dengan cita rasa makanan. Meskipun keaslian (authenticity) tidak dapat didefinisikan secara objektif (Grazien, 2003), pemilik restoran etnik khas Jawa meyakini bahwa penggunaan bahanbahan makanan tertentu yang didatangkan langsung dari Jawa akan dapat menghadirkan keaslian (authenticity) rasa masakan khas Jawa.

Adapun bahan-bahan yang khusus didatangkan dari Jawa adalah kecap, beras, tahu, kerupuk, dan teh. Alasan para pemilik restoran mendatangkan bahan-bahan tersebut langsung dari Jawa adalah karena menurut mereka, tekstur dan komposisi tanah dan air di Jawa berbeda dengan tekstur tanah dan air di Jakarta. Hal tersebut kemudian berpengaruh besar pada cita rasa makanan yang dihasilkan. Penggunaan bahan makanan yang asli dari Jawa diyakini dapat menghasilkan keaslian cita rasa masakan khas Jawa.

Bagaimanapun, upaya menghadirkan keaslian rasa dan budaya khas Jawa bukan berarti tidak memiliki tantangan. Bagi pemilik restoran khas Jawa, mendatangkan bahan-bahan makanan langsung dari Jawa memakan biaya yang tidak murah, sehingga hal tersebut berdampak pada harga jual makanan khas Jawa menjadi mahal. Belum lagi, apabila terjadi keterlambatan pengiriman bahanbahan makanan tersebut. Selain biaya yang tidak murah, dan terdapat kemungkinan keterlambatan pengiriman bahan makanan, daun jati pun mulai sulit dicari.

Tantangan lain yang mereka hadapi adalah saat ini adalah sebagian masyarakat Jakarta lebih memilih restoran yang tersedia di pusat-pusat perbelanjaan (mal). Sementara itu, pemilik restoran saat ini hanya mengandalkan word of mouth atau 'gethuk tular' untuk memperkenalkan bisnis kuliner mereka dan mengomunikasikan keaslian (authenticity) rasa dan budaya khas Jawa yang ada di restoran mereka. Dengan demikian belum banyak orang yang mengetahui restoran etnik khas Jawa tersebut.

\section{SIMPULAN}

Penggunaan dan pengelolaan elemen-elemen atmospheric dapat menjadi media yang tepat dalam menghadirkan keaslian (authenticity) rasa dan budaya Jawa dalam restoran etnik khas Jawa. Elemen atmospheric yang pertama adalah indra penglihatan (visual) manusia akan dengan mudah menangkap stimulus-stimulus yang tampak 'berbeda' atau tidak biasa mereka lihat. Banyak hal yang dapat digunakan untuk dijadikan stimulus indra penglihatan manusia. Mulai dari bangunan berbentuk joglo yang merupakan rumah khas Jawa, ukuran halaman yang luas, dominasi warna coklat yang ada pada penggunaan furnitur berbahan kayu, penggunaan artefak-artefak berupa stupa yang terbuat dari batu, maupun hiasan wayang kulit yang kental akan falsafah budaya Jawa.

Selain bangunan, desain interior dan eksterior, pemilik restoran memilih pakaian tertentu untuk dikenakan pelayan perempuan dan laki-laki. Kebaya dan jarik yang dikenakan pelayan, rias wajah dan tata rambut pelayan menggambarkan penampilan sehari-hari perempuan dan laki-laki Jawa. Demikian pula dengan peralatan makan yang masih didatangkan dari Jawa karena pemilik restoran melihat bahwa apabila mereka menggunakan peralatan makan yang umum dipakai di Jakarta akan mengurangi kesan keaslian (authenticity) budaya Jawa. Penyajian makanan pun sangat diperhatikan oleh pemilik restoran. Penggunaan daun pisang dan daun jati bertujuan untuk menyajikan keaslian cita rasa makanan. Pencahayaan juga harus diperhatikan, yaitu pencahayaan yang remang-remang.

Elemen kedua adalah aural atau indra pendengaran. Alunan suara gamelan, siter, dan tembang Jawa maupun lagu campur sari yang kerap dibawakan oleh para sinden bertujuan untuk menghadirkan keaslian suasana khas Jawa yang tenang dan sakral. 
Elemen ketiga adalah olfactory atau indra penciuman. Bau dari irisan pandan, bunga melati, dan bunga sedap malam tidak hanya menghasilkan bau wangi, tetapi juga memberikan kesegaran di dalam ruangan. Bau wangi irisan pandan, bunga melati, dan bunga sedap malam adalah bau khas Jawa dan dapat menggambarkan suasana keraton Jawa. Kesegaran juga mencerminkan kebersihan restoran yang dikelola. Selain bau pandan dan bunga, konsep dapur terbuka yang dipakai pemilik restoran menghasilkan bau masakan yang dimasak dengan kompor berbahan bakar arang. Bau masakan tersebut makin menambah keaslian rasa masakan khas Jawa.

Elemen keempat adalah tactile atau indra sentuhan atau peraba. Pemilik restoran memilih hanya menggunakan kipas angin untuk menjaga keaslian budaya khas Jawa karena rumah tradisional Jawa tidak menggunakan pendingin ruangan (AC). Selain itu, kipas angin dan sirkulasi udara yang baik tidak akan menyebabkan bau masakan tertinggal di pakaian para tamu yang datang.

Selain keempat elemen atmospheric tersebut, untuk menjaga keaslian (authenticity) rasa masakan khas Jawa, pemilik restoran mendatangkan bahan-bahan yang utama dipakai dalam masakan khas Jawa, seperti beras, kecap, tahu, kerupuk, dan teh. Pemilik restoran meyakini air dan tekstur tanah yang berbeda menghasilkan beras, kedelai, dan rasa daun teh yang berbeda pula.

Untuk dapat lebih memperkenalkan restoran etnik khas Jawa, pemilik restoran harus meningkatkan awareness masyarakat tentang restoran mereka. Salah satu caranya adalah dengan menyewakan restoran mereka untuk acara pernikahan dengan adat Jawa atau untuk arisan keluarga. Dengan demikian, tamu yang datang dan telah merasakan pengalaman unik khas Jawa akan melakukan 'gethuk tular' pada kenalan dan relasi mereka lainnya.

\section{Saran}

Saran untuk penelitian selanjutnya adalah bagaimana para tamu yang datang mempersepsikan keaslian (authenticity) rasa dan budaya khas Jawa yang ada pada restoran etnik khas Jawa tersebut. Serta elemen atmospheric apa yang dapat memberikan pengaruh paling kuat terhadap keaslian (authenticity) rasa dan budaya khas Jawa yang ada pada restoran etnik khas Jawa tersebut.

\section{DAFTAR PUSTAKA}

Ariyani, N. I. (2013). Strategi adaptasi orang Minang terhadap bahasa, makanan, dan norma masyarakat Jawa. Jurnal Komunitas Penelitian Sosiologi Antropologi dan Pembelajaran Sosiologi dan Antropologi, 5(1), 26-37.

Ebster, C., \& Guist, I. (2004). The role of authenticity in ethnic theme restaurants. Journal of Foodservice Business Research, 7(2), 41-52.

Grazian, D. (2003). Blue Chicago: The Search for Authenticity in Urban Blues Clubs. Chicago: University of Chicago Press.

Hamidi. (2007). Metode Penelitian Komunikasi dan Teori Komunikasi. Malang: UMM Press.

Jang, S., Liu, Y., \& Namkung, Y. (2010). Effects of authentic atmospherics in ethnic restaurants: investigating Chinese restaurants. International Journal of Contemporary Hospitality Management, 23(5), 662-680.

Kotler, P. (1973). Atmospherics as a Marketing Tool. Journal of Retailing, 49(4), 48-64. 
Moleong, L. (2007). Metodologi Penelitian Kualitatif. Bandung: Rosda.

Muñoz, C. L. \& Wood, N. T. (2009). A recipe for success: understanding regional perceptions of authenticity in themed restaurants. International Journal of Culture, Tourism and Hospitality Research, 3(3), $269-280$.

Neuman, W. L. (2003). Sosial Research Methods, Qualitative and Quantitative Approach. 5th Edition. USA: Pearson Education.

Patton, M. Q. (2002). Qualitative Research and Evaluation Methods. 3rd Edition. Thousand Oaks, California: Sage Publications.

Sarwono, J. (2006). Metode Penelitian Kuantitatif dan Kualitatif. Yogyakarta: Graha Ilmu.

Turley, L. W. \& Milliman, R. E. (2000). Atmospheric effects on shopping behavior: a review of the experimental evidence. Journal of Business Research, 49(2), 193-211.

Webster, L., \& Mertova, P. (2007). Using Narrative Inquiry As A Research Method. 1st Edition. Oxon: Routledge.

West, R., \& Turner, L. H. (2010). Introducing Communication Theories, Analysis and Application. $4^{\text {th }}$ Edition. New York: McGraw - Hill.

Wood, N. T., \& Munoz, C. L. (2006). 'No rules, just right' or is it? The role of themed restaurants as cultural ambassadors. Tourism and Hospitality Research, 7(3/4), 242-255. 